\title{
"The effectiveness of financial and economic regulation of land relations in the context of stimulating entrepreneurial activity in the regions of Ukraine"
}

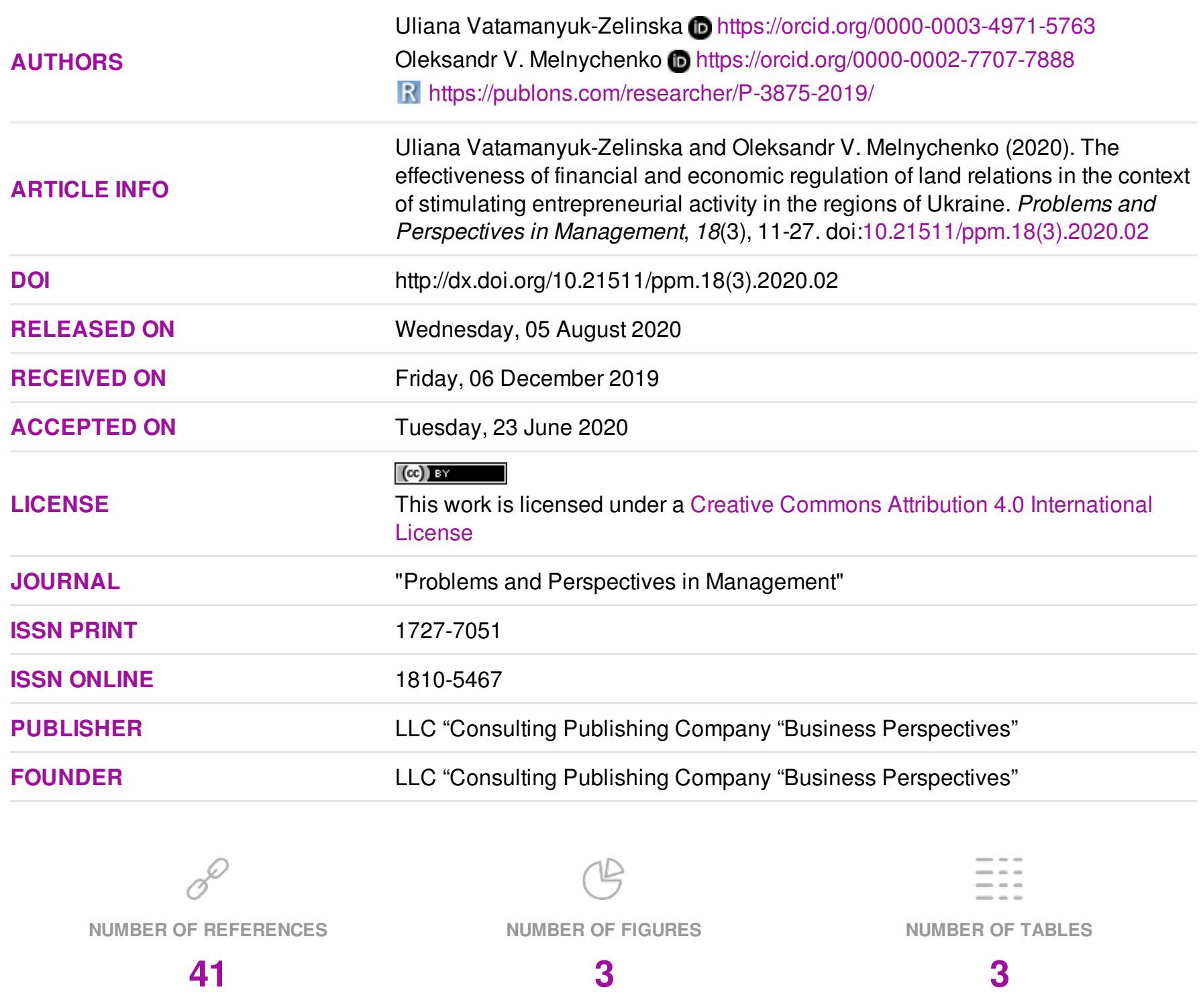

(c) The author(s) 2022. This publication is an open access article. 


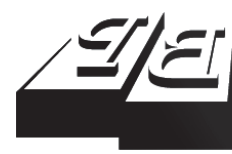

\section{BUSINESS PERSPECTIVES}

LLC "CPC "Business Perspectives" Hryhorii Skovoroda lane, 10, Sumy, 40022, Ukraine www.businessperspectives.org

Received on: $6^{\text {th }}$ of December, 2019 Accepted on: $23^{\text {rd }}$ of June, 2020 Published on: $5^{\text {th }}$ of August, 2020

๑ U Uliana Z. Vatamanyuk-Zelinska, Oleksandr V. Melnychenko, 2020

Uliana Z. Vatamanyuk-Zelinska, Ph.D. in Economics, Associate Professor, Professor of the Department of Financial Management, Ivan Franko Lviv National University, Ukraine. (Corresponding author)

Oleksandr V. Melnychenko, Doctor of Economics, Doctor habilitowany, Professor at the Department of Finance, Gdansk University of Technology, Poland.

\begin{abstract}
Solving the problem of enhancing the efficiency of the financial and economic regulation of land relations contributes to the development of entrepreneurship in Ukraine. The purpose of the paper is to determine new incentives for encouraging entrepreneurial activity by increasing the efficiency of the financial and economic regulation of land relations by local governments. The study is based on applying the method for predicting amounts of local budget revenues in Ukraine from the land tax and lease fees through the use of communally owned land plots to stimulate entrepreneurial initiatives of the unemployed. In the process of research, the projected amounts of local budget revenues from financial transactions with plots of industrial lands in each region of Ukraine have been determined, taking into account the possibilities of leasing the lands, for which lease fees are covered by a one-time benefit provided to the unemployed for organizing entrepreneurial activity. It is proposed to determine the efficiency of the financial and economic regulation of land relations in the regions of Ukraine, applying indicators such as the use of industrial lands together with objects of lease located on them and the involvement of the unemployed from among the economically active population in entrepreneurial activity. To improve the efficiency of financial and economic regulation of land relations, local governments are proposed to establish the optimal proportion of amounts of borrowed resources, taking into account the need for their saving and rational use.
\end{abstract}

Keywords

JEL Classification

\section{INTRODUCTION}

The problem of the lack of material and financial resources prompts local governments (LGs) to search for new sources of local budget revenues in order to ensure the balanced development of Ukrainian regions. Communally owned lands are the material basis for local governments in Ukraine. The use of communally owned lands for organizing entrepreneurial activity allows attracting additional local budget revenues. Therefore, enhancing the efficiency of the financial and economic regulation of land relations by local governments ensures the stimulation and development of entrepreneurship.

It is important for the country's economy to provide the stable functioning and intensive development of the entrepreneurship sector. Hence, the use of communally owned lands for organizing the entrepreneurial activity depends on the efficiency of the financial and economic regulation of land relations by local governments. The effi- 
ciency of the financial and economic regulation of land relations in terms of stimulating the entrepreneurship can be characterized by the rational and prudent use of communally owned lands being scarce resources within the material basis of local governments.

\section{LITERATURE REVIEW}

The efficiency is a comprehensive and complicated economic notion. Denis A. Grégoire and Naïma Cherchem describe it as the perception on the implementation as "a method of activity"; as drawing up new methodological indicators oriented toward certain results; as studying the main dynamics explaining causes and effects (Grégoire \& Cherchem, 2020). Nevertheless, efficiency examinations (given the comprehensive nature of this notion) continue to address a number of theoretical and methodological problems. Researchers consider it as: first, the productivity of activity (process, project, or measures taken) equaling a ratio of the economic effect obtained to the cost of resources that lead to the receipt of this result; second, a complex assessment of results of using all types of resources; third, the extent of achieving the objectives established (Morshchenok, 2016). Hence, the efficiency indicates a result of achieving a purpose depending on amounts of resources borrowed for this purpose. The efficiency of regulating land relations in terms of stimulating the entrepreneurial activity emerges under achieving an economic effect from applying incentives for encouraging this activity. The entrepreneurial activity contributes to the capitalization of communally owned lands of local governments and the formation of local budget revenues owing to revenues from lease fees of sole proprietors.

The authority of local governments in the area of land relations encompasses the disposition of lands of territorial communities, particularly making plots of communally owned lands available for use (The Verkhovna Rada of Ukraine, 2001). In addition, local governments exercise the authority in ensuring the local economic development through engaging investment and the development of entrepreneurship (The Cabinet of Ministers of Ukraine, 2014).

The economic efficiency is a criterion for assessing the activity of a local government and is expressed as a ratio between a result (effect) and expenses for achieving this result (Atamanchuk, 2006; Prykhodchenko, 2007). The activity of local governments in the area of regulating land relations requires substantiating its efficiency. The notion of efficiency is a managerial category, which indicates the degree of accomplishing established goals, i.e. a ratio between a result and goals or a result and expenses for achieving this result, and is the relative value calculated during a certain period (Krysak, 2015). It “...points to a connection with resources, a product, goals, and, obviously, with an effect..." (Potomkina, 2013). Thus, the efficiency of the activity of local governments in the sphere of regulating land relations depends on a result - an economic effect. The efficiency is different from the effect: the essence of the efficiency assumes that economists compute a ratio between achieved results and expenses, not the difference between results and expenses (Polehenka, 2016). The economic effect is achieved under exercising the authority of local governments in the sphere of regulating land relations to receive local budget revenues. Additional revenues of local budgets are accumulated through the use of incentives for stimulating entrepreneurial activity. Resources of own material and financial basis may be used in the form of incentives of local governments. A result of using land resources of communally owned lands for encouraging entrepreneurial activity is achieved through the accumulation of local budget revenues from lease fees.

A new concept of a flexible mixed decentralized model of management in Ukraine encourages local governments to mobilize taxes and save resources, particularly through the activation of the entrepreneurial activity development. This model consists in enhancing the extent of independence of local budgets and security budgets of regions (Kasiuk, 2016). The existence of own authority of local governments in the field of managing the material and financial basis, which is based on principles of the economic efficiency and economic expediency, affirms their financial independence (Dropa, 2017; Krysovatyy, Kyrylenko, Kneysler et al., 2017). Financial independence of local gov- 
ernments is embodied in the value of resources entirely or partially transferred to the local level alongside the established and delegated authority, as well as in the ability of local governments to efficiently manage them, i.e. to rationally use and increase them. Hence, the financial independence of local governments is an important precondition for the efficient financial and economic regulation of land relations, which fosters the rational use of land resources and encourages the development of entrepreneurship at the local level. The entrepreneurial activity provides budget-forming sources of local budget revenues in Ukraine, which include the land fee being a compulsory payment within the local tax for real estate, which is paid in the form of the land tax or lease fees for communally owned land plots (The Verkhovna Rada of Ukraine, 2010).

As a result, in the near future, local governments will become entirely dependent on local taxes for property and the business rather than subsidies. The results of research by Gobey and Matikonis (2019) and Asatryan, Baskaran, and Heinemann (2017) show that transferring the tax authority to the local level should ensure local budget revenues without applying state preferences. Consequences of decreased rate of the real estate tax for the small business indicate the higher dependence of local governments on the taxation of large corporations and restriction of the local autonomy. Regardless of whether small firms benefit from milder budgetary restrictions, such conditions foster the shortterm survival rather than growth. Moreover, the reduced rate of the real estate tax for the small business does not facilitate an increase in employment (Gobey \& Matikonis, 2019; Asatryan, Baskaran, \& Heinemann, 2017). Simultaneously, encouraging entrepreneurship is mainly related to providing productive employment, reducing inequality and decreasing social escalation in society as a guarantee of universal basic income and progressive taxation. Nowadays, tax instruments for the economic regulation of land relations in Ukraine are limited because they comprise only the land tax and lease fees for using land plots, as well as the single tax for the fourth group of taxpayers. However, the efficiency of financial and economic regulation of land relations at the local level depends on the exercise of the powers local governments regarding the establishment of the rate of land tax and the rental fee for land plots based on its normative monetary evaluation. Therefore, the economic effect from commercial transactions with land plots may be achieved through the compensation of these payments for the unemployed starting their own business. It is proposed to engage financial resources of the Unemployment Benefit Social Insurance Fund (UBSIF) in the form of the financial assistance for the unemployed to help them organize business and the amount of its balances at the end of the year.

Usually, entrepreneurship is examined from the standpoint of motivating an entrepreneur. However, the motivation in entrepreneurship should be considered as an economic process, which may be regulated to achieve a necessary positive economic effect from the economic activity of an entrepreneur. The motivation is considered as a particular set of tools for encouraging and forcing, which allows influencing the economic efficiency in managing the entrepreneurial activity (Kotliarevskyi, 2014). Therefore, making land plots available for organizing the entrepreneurial activity by the unemployed from among the economically active population will be an incentive for activating entrepreneurial initiatives among the unemployed and will ensure achieving the economic effect, as well as saving financial resources without decreasing the entrepreneur's profit. Nevertheless, the achievement of high efficiency in regulating land relations at the expense of profitable commercial transactions with land plots should be based on the principles of rational use and protection of lands, as well as taking into account the scarcity of this resource within the material basis of local governments.

The implementation of the State Target Program for Development of Land Relations in Ukraine declares solving most of socio-economic and ecological problems of the urban and rural land use, creating a stable market mechanism to regulate land relations, forming the financially-attractive land use, ensuring the creation of an integrated system of exercise bodies and local government agencies to manage land resources, improving economic and legal relations of land ownership, developing land management and economic regulation of the land use, and the phased launch of the economic circulation of land plots and rights to them (The 
Cabinet of Ministers of Ukraine, 2009). However, many economists point out that, to provide the efficient regulation of land relations, there is a need for the formation of a multi-sectoral economy based on the search for new forms of management for the efficient and rational use of land (Koroteyev, Korman, Manziy, Semenda, \& Semenda, 2017). At the current stage of economic transformations in Ukraine, directions of the financial and economic regulation of land relations should be declared in development strategies for each region of Ukraine, and should also be financed. In the context of the scarcity of their own resources, the activity of local governments in the field regulating land relations should be directed towards involving additional local budget revenues through the efficient use of lands, including those for organizing entrepreneurial activity. Such measures will allow local governments allocating borrowed funds for the preservation and reproduction of land resources of their own material basis.

Regardless of the organizational and legal structure, a type of activity, a sector of functioning of sole proprietors, and a type of commercial transactions with communally owned land plots of local governments, this influences the financial potential of sole proprietors, territories of local governments, and the development of entrepreneurship in each region of Ukraine. The creation of optimal economic conditions to form entrepreneurial potential of a region ensured by the efficient entrepreneurial activity is one of relevant goals of a regional economic policy (Shchehliuk, 2017). Its activation is also based on local strategies of regional development (Melnychenko, 2015). Regional strategies contemplate the main frameworks for regulating processes of the use, disposition, ownership, protection, and reproduction of land resources. However, current policies for stimulating the entrepreneurial activity in developing and developed countries are oriented towards facilitating the development of an entrepreneurial ecosystem: an interrelated system of efforts creating and supporting the regional entrepreneurship. Positive impacts of entrepreneurial ecosystems occur immediately at the stage of registration and spread to the economic activity of new business entities. These provide them with greater opportunities in managing and the optimal use of resources (Roundy \& Fayard, 2019). Nowadays, Ukraine has problems with delineating powers between local governments stipulated by the political situation, imperfection and incoherence of the institution of delegated powers, its inconsistency with European practice, a complicated system and the structure of managerial institutions, and the resulting excessive increase in budgetary spending (Buhlak, 2018; Pikhotskyi \& Rysin, 2019). Thus, the formation of entrepreneurial ecosystems in Ukraine with the participation of local governments is complicated. Simultaneously, to activate entrepreneurial activity, governmental officials have to combine incentives used by local governments with opportunities of the institutional, socio-cultural, organizational, and communication support on the part of other entities of financial relations.

\section{AIMS}

The aim of the paper is to identify new incentives for activating entrepreneurial activity by enhancing the efficiency of financial and economic regulation of land relations by local governments.

\section{METHODS}

Within the framework of the idea of the efficiency of financial and economic regulation of land relations in terms of stimulating entrepreneurial activity, the study proposes to use the following indicators:

- the efficiency of using industrial lands within built-up areas together with objects of lease located on them, which is calculated as the ratio of a rental fee (land tax) to an area of land plots, $\mathrm{UAH} / \mathrm{m}^{2}$ per year;

- the efficiency of involving the unemployed in the entrepreneurial activity, which is calculated as the ratio of a rental fee (land tax) for the use of land plots to the number of persons from among the unemployed who are registered as sole proprietors, $\mathrm{UAH} /$ person per year.

The indicators express the rate of the efficiency of using communally owned plots of industrial lands for organizing entrepreneurial activity 
and the rate of involving the unemployed in the entrepreneurial activity through making plots of industrial lands together with objects located on them available for lease. The calculation of these indicators is based on using the system and structural approach. The complex analysis of these indicators is the basis for determining amounts of material and financial resources that are essential for local governments in stimulating the development of entrepreneurship. The economic effect is achieved under the exercise of authority of local governments in regulating land relations in order to receive additional local budget revenues from lease fees. The prognostication method is used to determine amounts of local budget revenues from lease fees through the use of plots of industrial lands for organizing entrepreneurial activity and stimulating entrepreneurial initiatives of the unemployed.

The trend technique is used to predict total amounts of financial benefits to the unemployed for organizing entrepreneurial activity in the regions of Ukraine in the process of determining variants of involving resources to encourage the development of entrepreneurship. The option of involving resources at the level of $1 \%$ of amounts of the material assistance to the unemployed and the balance of the UBSIF was chosen, which is effective in the short run. To indicate the value of communally owned plots of industrial lands, statistical analysis is applied. The average rate of unemployment in Ukraine is used to identify the regions where stimulating entrepreneurial initiatives of the unemployed is a priority. The representativeness of indicators is affirmed by statistical data.

\section{RESULTS}

Receiving local budget revenues from land fees (the land tax and lease fees) of the unemployed starting their entrepreneurial activity is an important condition for the effectiveness of financial and economic regulation of land relations in terms of stimulating entrepreneurial activity. The efficiency of financial and economic regulation of land relations depends on the amount of resources attracted by local governments as incentives to activate entrepreneurial initiatives among the unemployed.
The growth in the number of the unemployed in Ukraine is one of the reasons for the need to intensify the entrepreneurial activity. Given the authority of local governments in the field of managing communal property, they may use resources of their own material basis to stimulate their entrepreneurial activity. Lands of territorial communities are subject to communal property rights. Local governments, on behalf of and in the interest of territorial communities, dispose with objects of the communal property right, they particularly conduct all property transactions, which may transfer objects of the right to communal property for the permanent or temporary use, especially to individuals (The Verkhovna Rada of Ukraine, 1997). Therefore, the efficiency of regulating land relations mainly depends on local governments.

The permanent deficit of budgetary funds and using reverse grants by the government require local governments to make new decisions for attracting additional local budget revenues. Financial transactions with communally owned land plots ensure such opportunity. This fact is affirmed by the positive dynamics of local budget revenues from fees for using land plots in Ukraine. The study observes the increase of these revenues by UAH $154,807.7$ thousand $(121.0 \%$ ) in 2015 , by UAH $921,086.9$ thousand (103.5\%) in 2016, by UAH $1,267,123.4$ thousand (103.5\%) in 2017, and by UAH 5,514.6 thousand (120.2\%) in 2018 (Figure 1).

This tendency is due to a decrease in the number of land fee deductions, the abolishment of the fixed agricultural tax and transferring this fee to the system of local taxes, as well as extending the tax base of the land tax. Despite positive dynamics, the proportion of revenues from the land fee in total revenues of local budgets of Ukraine is insignificant. This is particularly due to illicit financial transactions with land plots (WatamanyukZelinska \& Malets, 2018).

The proportion of revenues from the land fee in total revenues of local budgets is estimated at $5-7 \%$. An increase in land fees owing to the normative monetary evaluation of lands in compliance with new coefficients in 2018 has led to this situation. A ratio between amounts of revenues from lease fees and the land tax is $60 / 30$ (Vatamanyuk-Zelinska \& Sytnyk, 2019). 
Growth rates of revenues of oblast (regional) budgets and budgets of the cities of Kyiv and Sevastopol from the sale of communal lands and payments (fees) for communal lands, \%
Source: State Statistics Service of Ukraine $(2016,2017$, 2018a, 2019).

Structure of income from fees for the revenues of oblast (regional) budgets and budgets of cities of Kyiv and Sevastopol from the sale of communal lands and payments (fees) for communal lands, \%

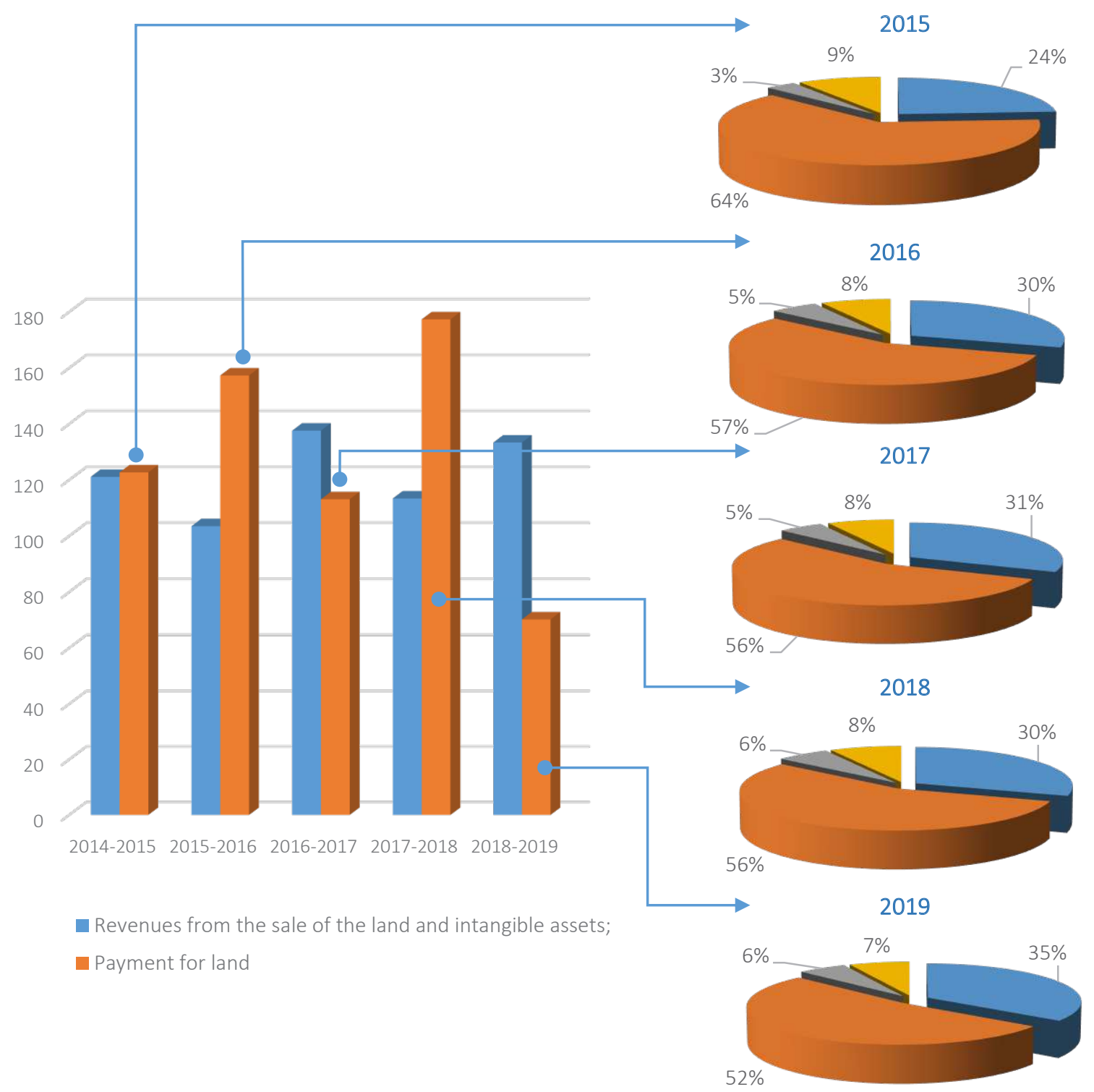

Note: With regard to payments (fees) for land (since fees, which had been referred to as land fees, fell under the category of local taxes in 2015, this name has not officially used; therefore, the use of this name in the article is due to the need to present data in a comparable format, since this name was used in previous periods), the data for 2014 are disclosed to compare trends that existed before implementing the reform of the hierarchy of territorial units, and tendencies that existed after implementing the reform in 2015.

\section{Figure 1. Growth rates and the structure of revenues in local budgets of Ukraine}

An increase in amounts of local budget revenues from land fees depends on the efficiency of regulating land relations and supporting entrepreneurial activity at the local level. The efficiency of financial and economic regulation of land relations also depends on the physical condition and amounts of land resources of local governments. This allows local governments to conduct financial transactions with land plots to raise local budget revenues at the expense of revenues from lease fees, land tax, and the single tax for the fourth group of taxpayers. 
To enhance the efficiency of the financial and economic regulation of land relations from the standpoint of stimulating the entrepreneurship, local governments are proposed to involve land resources, which are currently not used, to organize entrepreneurial activity. Objects located in the territory of large industrial enterprises (storages, plots, objects for warehouses and vehicles, etc.) do not presently function due to the decline in production (State Statistics Service of Ukraine, 2018b). With respect to objects administrated by military units, military units or any other permanent users of land plots are not eligible for their disposition since local governments similarly have the right to own these plots (The Verkhovna Rada of Ukraine, 2001). The situation with land plots being in the permanent use of other establishments, institutions, and organizations is analogical. None of them uses all the lands being available for exploitation simultaneously and entirely. The Ministry of Defence of Ukraine is ready to transfer approximately $10-15 \%$ of the total amount of lands (500 thousand ha) at the disposal of the Ministry for short-term lease (The Verkhovna Rada of Ukraine, 2017). Hence, local budget revenues in Ukraine from the lease of 50-75 thousand ha of industrial lands owned by the Ministry of Defence of Ukraine at the 3\% average normative monetary evaluation ( 907.38 thousand $\mathrm{UAH} / \mathrm{ha}$ ) will range from UAH 1,361,070.00 thousand to UAH 2,041,605.00 thousand per year.

Consequently, the communal property includes industrial lands used or intended for ensuring activities of industrial enterprises, as well as exploiting industrial objects. Citizens, as sole proprietors, may be users of such lands, since the Land Code of Ukraine does not establish direct restrictions on the acquisition of property rights or the use of land plots for the above purposes. Citizens and legal entities acquire property rights for the use of land plots from among communally owned lands according to the decision of local governments within their responsibility enshrined in the Land Code of Ukraine or according to the results of an auction (The Verkhovna Rada of Ukraine, 2001). Given the right to disposition of industrial lands, it should be noted that the right to ownership for a land plot from among industrial lands is inseparably linked to the property right for an industrial unit. In other words, the lease of communally owned industrial lands belonging to local governments will also contemplate exploiting industrial units located on such lands.

Therefore, plots of industrial lands, together with venues for the lease located on them, are the reserve of own resources of local governments to be proposed for organizing the entrepreneurial activity in order to stimulate its development. Stimulating the development of entrepreneurship helps enhance the efficiency of financial and economic regulation of land relations at the local level. Thus, achieving the economic effect relates to amounts of reserves of land resources belonged to local governments and their use to organize entrepreneurial activity, as well as to local budget revenues from the entrepreneurial activity taxation. The use of new incentives for activating the entrepreneurship by local governments is also concerned with the need to reduce unemployment rate in the regions of Ukraine. To overcome this problem, this study suggests making plots of industrial lands available for use by the unemployed who are registered as sole proprietors, and ensuring the reimbursement of lease fees and the land tax at the expense of financial benefits provided to the unemployed.

The unemployment benefit, including the one-time benefit for organizing the entrepreneurial activity by the unemployed, is provided to insured and uninsured persons being officially recognized as unemployed in accordance with the established procedure. An amount of the one-time benefit equals the annual sum of the unemployment benefit. It is calculated in accordance with the maximum and minimum amount of the benefit established by the board of directors of the Unemployment Benefit Social Insurance Fund as of the date of state registration of a legal entity or sole proprietor (The Ministry of Social Policy of Ukraine, 2015). Table 1 presents the projected amount of benefits provided by the UBSIF to the unemployed for organizing the entrepreneurial activity.

The proportion of the one-time benefit for launching own business in the total amount of material assistance in 2016-2017 is approximately $1 \%$. Thus, given the annual amounts of the balance of the Unemployment Benefit Social Insurance Fund, prognosticated amounts of payments of this benefit are estimated at: 
1) UAH 1,311,585.26 thousand - at the level of $1 \%$ of amounts of the material assistance for the unemployed and the balance of the UBSIF;

2) $710,988.98+1,193,086.10=1,904,075.08$ thousand UAH - at the level of $6 \%$ of the material assistance for the unemployed (at the beginning of $2020-6 \%$ of the material assistance, taking the existing balance of the UBSIF into account).

In the long term. this is expedient, since the volume of financial assistance will grow whereas the UBSIF balances should be liquidated.

It is proposed to direct funds of this assistance towards the coverage of lease fees and the land tax of registered sole proprietors from among the previously unemployed persons. Thus, the efficiency of the financial and economic regulation of land relations in terms of stimulating entrepreneurial activity will be determined according to the following indicators:

- the efficiency of using plots of industrial lands in built-up areas together with objects of lease located on them, which shows the annual amounts of local budget revenues from the lease of a unit of such an area;

- the efficiency of involving the unemployed in the entrepreneurial activity, which shows the amount of revenues from the lease fee or land tax that one sole proprietor pays to a local budget per year at the expense of funds of the one-time benefit for starting his/her own business.

The efficiency of financial and economic regulation of land relations from the standpoint of stimulating the entrepreneurship is achieved through obtaining the maximum benefit (the projected amounts of local budget revenues from the lease fees and land tax reimbursed by funds of the financial benefit provided by the UBSIF) from the minimum amounts of engaged resources $-0.1 \%$ of industrial lands in built-up areas together with objects of lease located on them and $0.1 \%$ of the general number of the unemployed involved in the entrepreneurial activity in each region of Ukraine.

The projected amounts of own revenues of corresponding local budgets $\left(D_{n}\right)$ from the lease fee and land tax owing to involving financial resources of the UBSIF $\left(V_{U B S I F}\right)$ are determined in compliance with the following model:

$D_{n}=S_{p} \frac{0.1}{100} \cdot N M E \frac{3}{100} \cdot U_{15-70} \cdot \frac{0.1}{100}$, thousand

UAH per year

where $n$ - local budget; $S_{p}$ - plots of industrial lands in built-up areas together with objects of lease located on them, $\mathrm{m}^{2} ; U_{15-70}$ - the number of the unemployed from among the economically active population, persons; and NME - normative monetary evaluation of land plots, $\mathrm{UAH} / \mathrm{ha}$;

The efficiency of involving the unemployed in the entrepreneurial activity is determined in compliance with the following model:

- for regions where the unemployment rate is higher than the average in Ukraine:

$E_{U_{15-70}}=\frac{D_{n}}{U_{15-70}} \cdot 0.1 \%$, UAH/persons;

- for regions with the lower unemployment rate (within the UBSIF balance after the allocation among regions with above average unemployment rate):

$E_{U_{15-70}}=\frac{V_{U B S I F_{b}}}{E_{U_{15-70}}} \cdot 0.1 \%$, UAH/persons.

The efficiency of using industrial lands in builtup areas together with objects of lease located on them $\left(E_{s_{p}}\right)$ :

- for regions where the unemployment rate is above the average for Ukraine:

$E_{s_{p}}=\frac{D_{n} \cdot 1,000}{S_{n} \cdot 0.1 \% \cdot 10,000}, \mathrm{UAH} / \mathrm{m}^{2}$;

- for regions where the unemployment rate is below the average for Ukraine (within the UBSIF balance after the allocation among regions with above average unemployment rate):

$E_{s_{p}}=\frac{V_{U B S I F_{b}} \cdot 1,000}{0.1 \% \cdot 10,000}, \mathrm{UAH} / \mathrm{m}^{2}$

Table 2 shows the results of calculating the indicators of the efficiency of financial and economic regulation of land relations on the level of each region of Ukraine. 
Table 1. Projected amounts of benefits provided by UBSIF to the unemployed for organizing the entrepreneurial activity

Source: The Cabinet of Ministers of Ukraine (2016, 2017, 2018, 2019a, 2019b).

\begin{tabular}{|c|c|c|c|c|c|c|c|c|}
\hline \multirow[b]{2}{*}{ Period } & \multirow{2}{*}{$\begin{array}{l}\text { Unemployment benefit, } \\
\text { thousand UAH }\end{array}$} & \multirow{2}{*}{$\begin{array}{l}\text { UBSIF balance at } \\
\text { the beginning of the } \\
\text { year, thousand UAH }\end{array}$} & \multirow{2}{*}{$\begin{array}{l}\text { Amounts of } \\
\text { the benefits } \\
\text { provided to the } \\
\text { unemployed } \\
\text { when organizing } \\
\text { entrepreneurial } \\
\text { activity, UAH }\end{array}$} & \multirow{2}{*}{$\begin{array}{c}\text { Proportion } \\
\text { of benefits } \\
\text { in the total } \\
\text { amount of } \\
\text { material } \\
\text { assistance, } \%\end{array}$} & \multirow{2}{*}{$\begin{array}{l}\text { Proportion of } \\
\text { benefits and } \\
\text { balance in the } \\
\text { total amount } \\
\text { of material } \\
\text { assistance, \% }\end{array}$} & \multirow{2}{*}{$\begin{array}{l}\text { Relative } \\
\text { dynamics of the } \\
\text { increase in the } \\
\text { UBSIF balance } \\
\text { (compared to } \\
\text { the previous } \\
\text { year), } \%\end{array}$} & \multicolumn{2}{|c|}{$\begin{array}{l}\text { Projected amounts of benefits in } \\
2020 \text {, thousand UAH }\end{array}$} \\
\hline & & & & & & & $\begin{array}{l}\text { At the level of } 1 \% \\
\text { of amounts of the } \\
\text { benefits and the } \\
\text { UBSIF balance }\end{array}$ & $\begin{array}{c}\text { At the level of } \\
6 \% \text { of amounts } \\
\text { of the material } \\
\text { assistance }\end{array}$ \\
\hline 2016 & $6,662,027.20$ & $353,508.50$ & $69,313.9$ & 1.04 & 6.30 & - & \multirow{6}{*}{$1,311,584.26$} & \multirow{6}{*}{$710,988.98$} \\
\hline 2017 & $8,514,417.80$ & $426,264.10$ & $46,412.6$ & 0.54 & 5.55 & 20.59 & & \\
\hline 2018 & $8,993,835.60$ & $1,010,062.50$ & - & - & - & 136.96 & & \\
\hline 2019 & $9,661,478.00$ & $1,958,951.50$ & - & - & - & 193.94 & & \\
\hline $\begin{array}{l}\text { At the beginning of } \\
2020\end{array}$ & $11,849,816.60$ & $1,193,086.10$ & - & - & - & 60.90 & & \\
\hline Average & $9,136,314.98$ & $988,374.54$ & $57,863.25$ & 1 & 6 & 72.65 & & \\
\hline
\end{tabular}




\begin{tabular}{|c|c|c|c|c|c|c|c|c|c|c|c|}
\hline \multirow[b]{2}{*}{ 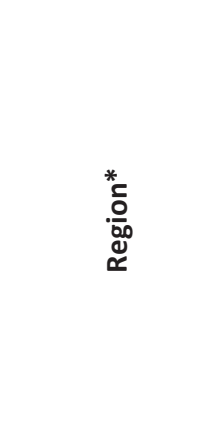 } & \multirow[b]{2}{*}{ 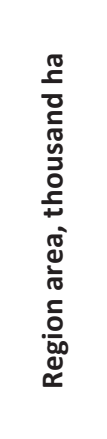 } & \multirow[b]{2}{*}{ 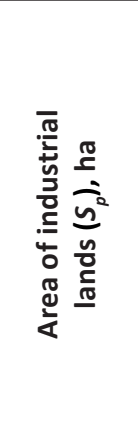 } & \multirow[b]{2}{*}{ 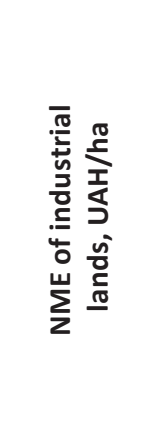 } & \multirow[b]{2}{*}{ 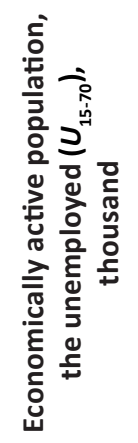 } & \multicolumn{3}{|c|}{$\begin{array}{c}\text { Unemployment benefit for organizing } \\
\text { entrepreneurial activity }\end{array}$} & \multirow[b]{2}{*}{ 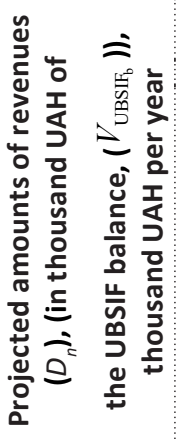 } & \multirow[b]{2}{*}{ 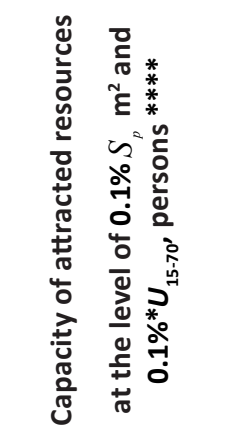 } & \multicolumn{2}{|c|}{ Efficiency } \\
\hline & & & & & 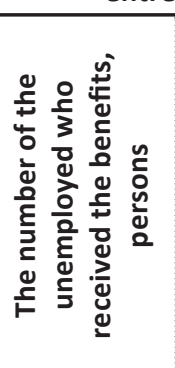 & 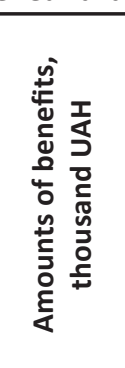 & 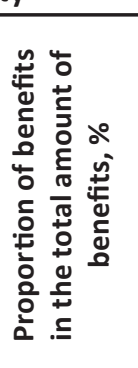 & & & 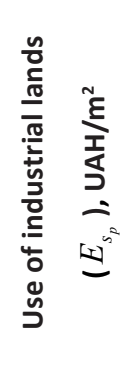 & 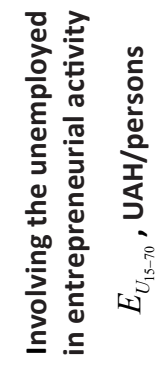 \\
\hline Vinnytsia & $2,651.3$ & $7,787.8$ & $724,925.0$ & 76.5 & 105.0 & $2,755.5$ & 5.93 & $12,956.59$ & $77,878 / 77$ & 166.37 & $168,267.40$ \\
\hline Volyn & $2,014.4$ & $3,184.7$ & $736,434.0$ & 52.1 & 148.0 & $2,724.10$ & 5.87 & $(59,377.97)$ & $31,847 / 844$ & $1,864.48$ & $70,353.05$ \\
\hline Dnipropetrovsk & $3,191.4$ & $27,802.4$ & $1,823,581.0$ & 129.2 & 132.0 & $2,756.30$ & 5.93 & $196,512.92$ & $278,024 / 129$ & 706.82 & $1,523,355.97$ \\
\hline Donetsk** & $2,651.7$ & $29,528.4$ & $737,500.0$ & 125.3 & 85.0 & $2,419.70$ & 5.21 & $81,860.48$ & $295,284 / 125$ & 277.23 & $654,883.84$ \\
\hline Zhytomyr & $2,983.2$ & $6,107.3$ & $442,593.0$ & 62.0 & 27.0 & 654.10 & 1.40 & $(59,377.97)$ & $61,073 / 732$ & 972.25 & $81,117.45$ \\
\hline Zakarpattia & $1,277.7$ & $2,594.9$ & $1,424,239.0$ & 58.2 & 75.0 & $1,423.90$ & 3.07 & $(59,377.97)$ & $25,949 / 536$ & $2,288.26$ & $110,779,79$ \\
\hline Zaporizhzhia & $2,718.0$ & $7,924.9$ & $788,122.0$ & 86.2 & 97.0 & $2,752.10$ & 5.93 & $16,151.61$ & $79,249 / 86$ & 203.81 & $187,809.42$ \\
\hline Ivano-Frankivsk & $1,390.0$ & $6,281.4$ & $1,196,881.0$ & 51.9 & 67.0 & $2,077.70$ & 4.48 & $(59,377.97)$ & $62,814 / 263$ & 945.30 & $225,771.75$ \\
\hline Kyiv*** & $2,813.1$ & $11,736.9$ & $566,200.0$ & 153.0 & 230.0 & $7,670.10$ & 16.53 & $30,502.54$ & $117,369 / 153$ & 259.89 & $199,363,01$ \\
\hline Kirovohrad & $2,458.8$ & $10,581.0$ & $743,817.0$ & 52.9 & 40.0 & $1,096.00$ & 2.36 & $(59,377.97)$ & $105,810 / 252$ & 561,18 & $235,626.87$ \\
\hline Luhansk & $2,668.4$ & $14,184.9$ & $360,561.0$ & 58.3 & 32.0 & $1,309.20$ & 2.82 & $(59,377.97)$ & $141,849 / 387$ & 418.60 & $153,431.45$ \\
\hline Lviv & $2,183.3$ & $9,941.0$ & $371,183.0$ & 85.8 & 172.0 & $2,943.10$ & 6.34 & $9,497.88$ & $99,410 / 86$ & 95.54 & $110,440.47$ \\
\hline Mykolaiv & $2,459.8$ & $5,209.9$ & $1,173,120.0$ & 56.3 & 40.0 & $1,177.10$ & 2.54 & $(59,377.97)$ & $52,099 / 324$ & $1,139.71$ & $183,265.34$ \\
\hline Odesa & $3,331.0$ & $6,535.2$ & $907,380.0$ & 77.2 & 60.0 & $1,539.60$ & 3.32 & $13,733.67$ & $65,352 / 77$ & 210.15 & $178,359.35$ \\
\hline Poltava & $2,874,8$ & $11,784.9$ & $745,421.0$ & 78.3 & 58.0 & $1,252.10$ & 2.70 & $20,635.29$ & $117,849 / 78$ & 175.10 & $264,555.00$ \\
\hline Rivne & $2,004.7$ & $4,684.3$ & $110,100.0$ & 60.1 & 79.0 & $1,681.30$ & 3.62 & $(59,377.97)$ & $46,843 / 3838$ & $1,267.60$ & $15,471.07$ \\
\hline Sumy & $2,383.4$ & $8,564.0$ & $956,875.0$ & 48.0 & 44.0 & $1,163.60$ & 2.51 & $(59,377.97)$ & $85,640 / 242$ & 693.34 & $245,363.51$ \\
\hline Ternopil & $1,982.3$ & $3,220.5$ & $907,653.0$ & 53.9 & 33.0 & 585.40 & 1.26 & $(59,377.97)$ & $32,205 / 677$ & $1,843.75$ & $87,707,49$ \\
\hline Kharkiv & $3,141.5$ & $11,625.0$ & $1,393,201.0$ & 80.4 & 72.0 & $1,863.30$ & 4.01 & $39,064.66$ & $116,250 / 80$ & 336.04 & $488,308.25$ \\
\hline Kherson & $2,846.1$ & $4,430.8$ & $2,715,955.0$ & 55.0 & 58.0 & $1,465.10$ & 3.16 & $(59,377.97)$ & $44,308 / 165$ & $1,340.12$ & $359,866.48$ \\
\hline Khmelnytskyi & $2,064.5$ & $5,914.8$ & $628,372.0$ & 50.2 & 97.0 & $1,578.50$ & 3.40 & $(59,377.97)$ & $59,148 / 533$ & $1,003.89$ & $111,403.32$ \\
\hline Cherkasy & $2,090.0$ & $6,630.7$ & $674,618.0$ & 59.2 & 58.0 & $1,872.90$ & 4.07 & $(59,377.97)$ & $66,307 / 443$ & 895.50 & $134,036.05$ \\
\hline Chernivtsi & $8,097.0$ & $1,974.2$ & $1,021,342.0$ & 34.8 & 13.0 & 358.50 & 0.77 & $(59,377.97)$ & $19,742 / 982$ & $3,007.70$ & $60,466.36$ \\
\hline Chernihiv & $3,186.5$ & $4,466.9$ & $626,989.0$ & 53.5 & 40.0 & $1,293.00$ & 2.79 & $(59,377.97)$ & $44,669 / 707$ & $1,329.29$ & $83,985.81$ \\
\hline Ukraine & $\begin{array}{c}\text { Total } \\
57,575.6\end{array}$ & $\begin{array}{c}\text { Total } \\
212,698.8\end{array}$ & $\begin{array}{l}\text { Average } \\
907,380.0\end{array}$ & $\begin{array}{c}\text { Total } \\
1,698.0\end{array}$ & $\begin{array}{c}\text { Total } \\
1,862.0\end{array}$ & $\begin{array}{c}\text { Total } \\
46,412.0\end{array}$ & $\begin{array}{l}\text { Total } \\
100.0\end{array}$ & $\begin{array}{c}\text { Total } \\
1,311,585.19\end{array}$ & $\begin{array}{c}\text { Total } \\
2,126,968 / 11,816\end{array}$ & $\begin{array}{l}\text { Average } \\
916.75\end{array}$ & $\begin{array}{c}\text { Average } \\
247,250.00\end{array}$ \\
\hline
\end{tabular}

Notes: * Data exclude the temporarily occupied territory of the Autonomous Republic of Crimea, the city of Sevastopol and a part of temporarily occupied territories in the Donetsk and Luhansk regions; ${ }^{* *}$ the sums of lease fees are calculated at the level of the minimum rate in a region; ${ }^{* * *}$ the sum of lease fee in the city of Kyiv is included in the indicator for the Kyiv oblast; ${ }^{* * * *}$ plots in built-up areas are measured in $\mathrm{m}^{2}$. 
The amounts of local budget revenues from the land fee were calculated, which are reimbursed at the expense of funds of the financial benefit for organizing the entrepreneurial activity provided by the UBSIF, at the $3 \%$ NME. This is stipulated by the necessity for considering the taxation method chosen by the unemployed person who is registered as a sole proprietor. According to a traditional tax system, a sole proprietor is a payer of the land tax, whereas, according to a simplified tax system, a sole proprietor has to pay lease fees. Local governments establish rates of lease fees and land tax deductions paid in the territory of local government on their own. The Ukrainian legislation establishes the rate of land tax for plots for which the normative monetary evaluation has been carried out (regardless of location). This rate must not exceed $3 \%$ of the normative monetary evaluation of such plots. Single tax payers are exempt from the land fee in the form of land tax. If a single tax payer leases lands owned by local governments, he/she has to pay the land fee in the form of a lease fee. Single tax payers are not exempt from lease fees. The annual sum of lease fees cannot be less than the sum of the land tax (The Verkhovna Rada of Ukraine, 2010).

The highest rate of unemployment is observed in the Dnipropetrovsk (129.2 thousand persons), Donetsk (125.3 thousand persons), Zaporizhzhia (86.2 thousand persons), and Odesa (77.2 thousand persons) oblasts. This tendency is due to political consequences of the armed conflict in Ukraine. Hence, the internal migration of the unemployed from among the internally displaced persons leads to an increase in the unemployment rate in industrially developed regions - Lviv (85.8 thousand persons), Kyiv (153.00 thousand persons), Kharkiv (80.4 thousand persons), Poltava (78.3 thousand persons), and Vinnytsia (76.5 thousand persons). In addition, the study focuses on the fact of massive emigration of the unemployed from among the economically active population (this tendency is inherent to border oblasts).

Therefore, local governments in the Vinnytsia, Dnipropetrovsk, Donetsk, Zaporizhzhia, Kyiv, Lviv, Odesa, Poltava, and Kharkiv oblasts where the unemployment rate is higher than the average for Ukraine (exceeds 70 thousand persons) are proposed to primarily use incentives to encourage entrepreneurial activity through enhancing the efficiency of financial and economic regulation of land relations. For instance, the projected amounts of local budget revenues in the Vinnytsia region are as follows:

$$
\begin{aligned}
& D_{n}=(7,787.8 \cdot 0.1 \%) \cdot(724,925.00 \cdot 3 \%) \times \\
& \times(76.5 \cdot 0.1 \%)=12,956.59
\end{aligned}
$$

(thousand UAH per year).

The indicator values of the efficiency of financial and economic regulation in land relations: $E_{U_{15-70}}=168,267.40 \mathrm{UAH} /$ persons

$$
\begin{aligned}
& \left(\begin{array}{l}
E_{U_{15-70}}=12,956,590.00 / 77 \cdot 0.1 \%= \\
=168,267.40
\end{array}\right) \text { and } \\
& E_{s_{p}}=166.37 \mathrm{UAH} / \mathrm{m}^{2} \\
& \left(E_{s_{p}}=\frac{12,956,590.00}{7,787.8 \cdot 0.1 \% \cdot 10,000.00}=166.37\right) .
\end{aligned}
$$

For the regions where the unemployment rate is higher than the average for Ukraine, the economic effect from involving $0.1 \%$ of areas of industrial lands $\left(E_{s p}=124,666.5 \mathrm{ha}\right)$ for organizing entrepreneurial activity of $0.1 \%$ of the unemployed ( $U_{15-70}=891.9$ thousand persons) amounts to $\mathrm{UAH}$ $420,915.64$ thousand per year.

The balance of the financial benefit provided by the UBSIF to the unemployed for organizing entrepreneurial activity after the allocation among nine regions with high unemployment rate accounts for UAH 890,669.62 thousand. The balance is proportionally distributed between the other fifteen Ukrainian oblasts $((1,311,585.26$ - 420,915.64)/15 $=59,377.97$ (thousand UAH/oblast)).

For instance, in the Volyn oblast, within UAH $59,377.97$ thousand of the projected amounts of local budget revenues from lease fees and the land tax, local authorities may employ 844 persons

$\left(\begin{array}{l}U_{15-70}=\frac{59,377,970.00}{(3,184.7 \cdot 736,434.00 \cdot 3 \%) \cdot 0.1 \%}= \\ =844\end{array}\right)$

owing to attracting the UBSIF financial resources and leasing out $31,847.00 \mathrm{~m}^{2}$ of industrial lands $\left(S_{p}=3,184.7 \cdot 0.1 \%=31,847.00 \quad(\mathrm{ha})=31,847.00\right)$. 
Simultaneously, the efficiency of using areas of industrial lands in built-up areas together with objects of lease located on them is $1,864.48 \mathrm{UAH} / \mathrm{m}^{2}$ $\left(E_{15-70}=59,377,970.00 / 3,184.7 \cdot 0.1 \% \cdot 10,000.00=1,86\right.$ 4.48 ), while the efficiency of involving the unemployed in the entrepreneurial activity amounts to 1,139,692.32 UAH/persons

$$
\left(E_{s_{p}}=\frac{59,377,970.00}{52,1 \cdot 1,000 \cdot 0.1 \%}=1,139,692.32\right) \text {. }
$$

In general, in the oblasts with the unemployment rate lower than the average for Ukraine, the economic effect from involving $0.1 \%$ of areas of industrial lands $\left(S_{p}=88030.3 \mathrm{ha}\right)$ for organizing the entrepreneurial activity of $0.1 \%$ of the unemployed $\left(U_{15-70}=10.93\right.$ thousand persons) amounts to UAH $1,311,585.26$ thousand per year.

Land resources of the material basis of local governments alongside financial resources of the UBSIF are scarce. This fact leads to the need for their rational use and saving. Thus, local governments deal with the problem of establishing the rate for amounts of borrowed resources and the number of the unemployed entitled for them. The efficiency indicators of financial and economic regulation of land relations associated with the use of resources and involvement of the unemployed are shown in Table 3.

Figures 2 and 3 shows the indicators of the efficiency of financial and economic regulation of land relations associated with the use of resources and involvement of the unemployed in the regions of Ukraine.

In the Vinnytsia (166.37 $\left.\mathrm{UAH} / \mathrm{m}^{2}\right)$, Lviv (95.54 $\left.\mathrm{UAH} / \mathrm{m}^{2}\right)$, Odesa $\left(210.15 \mathrm{UAH} / \mathrm{m}^{2}\right)$, and Poltava $\left(175.10 \mathrm{UAH} / \mathrm{m}^{2}\right)$ oblasts, the efficiency of using areas of industrial lands in built-up areas together with objects of lease located on them is the lowest. This tendency is due to the low value of the normative monetary evaluation of land. Thus, the value of lease and the rate of land tax are also low. Consequently, the number of unemployed persons wishing to start own business and to express the entrepreneurial initiative will rise. Hence, it is proposed to use such areas for organizing entrepreneurial activity at the level of $0.01 \%$ of their total amount (Table 3, Figure 2 and Figure 3). An argument in favor of such decisions implies

Table 3. Indicators of the efficiency of financial and economic regulation of land relations associated with the use of resources and involvement of the unemployed

Source: Based on Table 2 calculations.

\begin{tabular}{|c|c|c|c|c|c|}
\hline \multirow[b]{2}{*}{ Region } & \multirow[b]{2}{*}{$\begin{array}{l}\text { Projected amounts } \\
\text { of revenues }\left(D_{n}\right) \text { (in } \\
\text { thousand UAH of } \\
\text { the UBSIF balance } \\
\left(V_{U B S I F_{b}}\right) \text {, thousand } \\
\text { UAH per year }\end{array}$} & \multirow[b]{2}{*}{$\begin{array}{c}\text { Amounts of using } \\
\text { land resources, } \\
\text { the number of the } \\
\text { involved unemployed, } \\
\text { at the level of } 0.1 \% \\
S_{p} \text { and } 0.1 \% U_{15-70} \\
\text { persons }\left(\mathrm{m}^{2}\right)\end{array}$} & \multirow[b]{2}{*}{$\begin{array}{l}\text { Rate of using the } \\
\text { land resources } \\
\text { or involving the } \\
\text { unemployed, \%/ } \\
\text { persons }\left(\mathrm{m}^{2}\right)\end{array}$} & \multicolumn{2}{|c|}{$E_{U_{15-70}},\left(\mathbf{E}_{\mathrm{Sp}}\right)$, per year } \\
\hline & & & & $\begin{array}{l}\text { At the level } \\
\text { of } 0.1 \% S_{p} \\
\text { and } 0.1 \% \\
U_{15-70^{\prime}}, \mathrm{UAH} / \\
\text { persons } \\
\left(\mathrm{UAH} / \mathrm{m}^{2}\right)\end{array}$ & $\begin{array}{c}\text { At the established } \\
\text { level, UAH/ } \\
\text { persons }\left(\mathrm{UAH} / \mathrm{m}^{2}\right) / \\
S_{p} \text { average }\end{array}$ \\
\hline Dnipropetrovsk & $196,512.92$ & 129 & $1 \% U_{15-70} / 1,292$ & $1,523,355.97$ & $152,099.70$ \\
\hline Donetsk & $81,860.48$ & 125 & $1 \% U_{1570} / 1,253$ & $654,883.84$ & $65,331.50$ \\
\hline Kharkiv & $39,064.66$ & 80 & $1 \% U_{15-70} / 804$ & $488,308.25$ & $48,587.80$ \\
\hline Kherson & $59,377.97$ & 165 & $1 \% U_{15-70} / 1,650$ & $359,866.48$ & $35,988.60$ \\
\hline Zaporizhzhia & $7,924.9$ & $(79,249.00)$ & $1 \% S_{p} /(792,490)$ & $(203.81)$ & $(20,308.1)$ \\
\hline Rivne & $59,377.97$ & 3838 & $0.05 \% U_{15-70} / 1,919$ & $15,471.07$ & 30,942 \\
\hline Zhytomyr & $59,377.97$ & 732 & $0.05 \% U_{15-70} / 366$ & $81,117.45$ & $162,234.8$ \\
\hline Ternopil & $59,377.97$ & 677 & $0.05 \% U_{15-70} / 339$ & $87,707.49$ & $175,156.25$ \\
\hline Chernihiv & $59,377.97$ & 707 & $0.05 \% U_{15-70} / 354$ & $83,985.81$ & $167,734.3$ \\
\hline Vinnytsia & $12,956.59$ & $(77,878)$ & $0.01 \% S_{p} /(7,788)$ & $(166.37)$ & $(1,663.66 / 916.75)$ \\
\hline Lviv & $9,497.88$ & $(99,410)$ & $0.01 \% S_{p} /(9,941)$ & 95.54 & $(955.4)$ \\
\hline Odesa & $13,733.67$ & $(65,352)$ & $0.01 \% S_{p} /(6,535)$ & $(210.15)$ & $(2,101.56 / 916.75)$ \\
\hline Poltava & $20,635.29$ & $(117,849)$ & $0.01 \% S_{p} /(11,785)$ & $(175.10)$ & $(1,750.9 / 916.75)$ \\
\hline \multirow{2}{*}{ Chernivtsi } & $59,377.97$ & $(19,742)$ & $1 \% S_{p} /(197,420)$ & $(3,007.7)$ & $(300.7)$ \\
\hline & $59,377.97$ & 982 & $0.05 \% U_{15-70} / 491$ & $60,466.36$ & $120,932.7$ \\
\hline
\end{tabular}


Source: Based on calculations according to Tables 2 and 3.

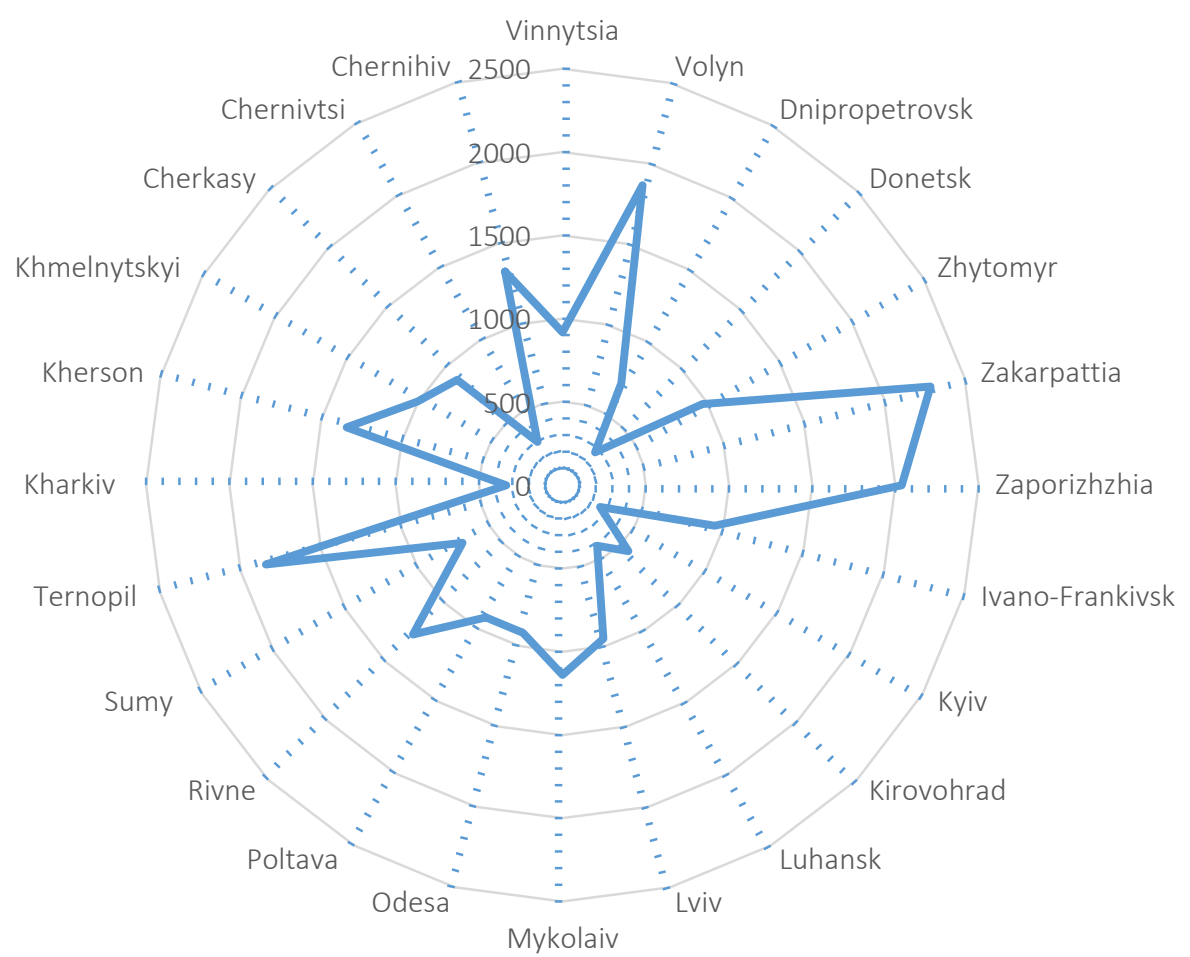

Figure 2. Indicators of the efficient regulation of land relations associated with the use of industrial land in built-up areas, together with the lease objects located on them, UAH/m²

Source: Based on calculations according to Tables 2 and 3.

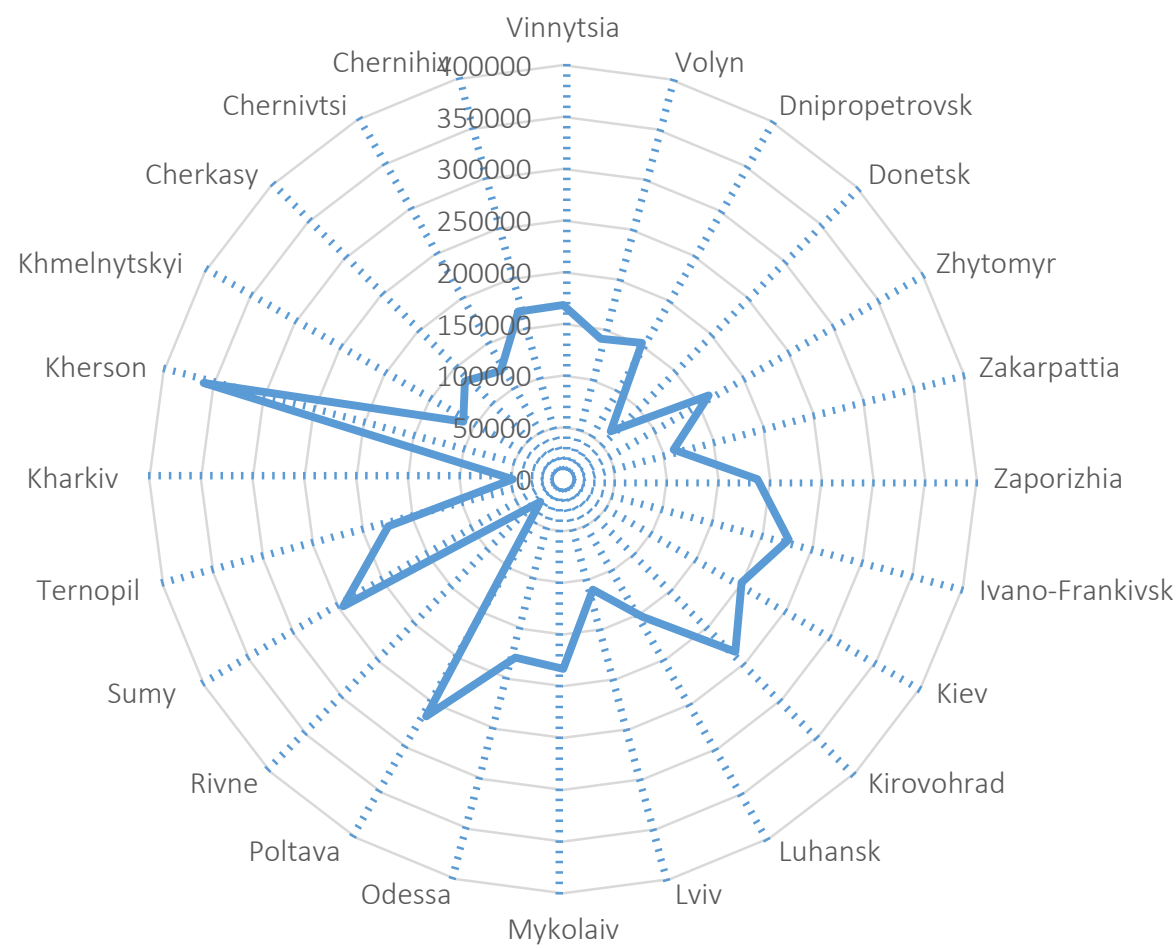

Figure 3. Indicators of the efficient regulation of land relations associated with the involvement of the unemployed in entrepreneurial activity, $\mathrm{UAH} /$ persons 
maintaining the value of leasing the communally owned lands for unemployed persons on the level of its average value for Ukraine (namely, 916.75 $\mathrm{UAH} / \mathrm{m}^{2}$ ) at the stage of starting the entrepreneurial activity. Therefore, to avoid a decrease in local budget revenues, local governments should establish the marginal amount of lease fees and land tax rates at the level of $1-2 \%$ of the normative monetary evaluation for communally owned industrial lands.

To enhance the efficiency of involving industrial lands together with lease objects located on them in the Zaporizhzhia oblast (up to 20,308.1 UAH/ $\mathrm{m}^{2}$ ), it is offered to use $1 \%$ of the total area of industrial lands in the region. This will allow increasing the number of the unemployed who tend to register as sole proprietors under such terms, from 86 to 149 persons.

The high value of an indicator of financial and economic regulation of land relations associated with the involvement of the unemployed in entrepreneurial activity is observed in the Dnipropetrovsk $(1,523,355.97 \mathrm{UAH} /$ person$)$, Donetsk $(654,883.84$ UAH/person), and Kharkiv $(488,308.25 \mathrm{UAH} /$ person) oblasts. Given the high unemployment rate in these regions, it is offered to involve the greater number of the unemployed - at the level of $1 \%$ of economically active unemployed population in each oblast - in entrepreneurial activity (Table 3, Figure 2, and Figure 3).

The low indicator of the efficiency of financial and economic regulation of land relations associated with the involvement of the unemployed in entrepreneurial activity is observed in the Rivne $(15,471.07 \mathrm{UAH} /$ person), Chernivtsi $(60,466.36$ UAH/person), Zhytomyr (81,117.45 UAH/person), Ternopil (87,707.49 UAH/person), and Chernihiv $(83,985.81 \mathrm{UAH} /$ person) oblasts. This is due to the high value of the lease and land tax rate, which depend on the high normative monetary evaluation established in the territory of these regions. To enhance this indicator, it is suggested to restrict the number of persons involved in entrepreneurial activity at the level of $0.05 \%$ of the economically active unemployed population of the regions (Table 3 , Figures 2 and 3). The amount of the unemployment benefit provided by the Unemployment Benefit Social Insurance Fund for these oblasts is distributed according to the leftover principle. Hence, the amount of such benefit is insufficient to cover expensive lease fees and higher rates of the land tax for many persons.

The activity of local governments in the field of financial and economic regulation of land relations, based on cooperation with UBSIF, is only the first step towards the formation of an ecosystem for support and development of entrepreneurship. The proposed approach helps stimulate the development of regional entrepreneurship and provides conditions only for starting a business in a region not defining the boundaries of its functioning. Further development of such systems requires a wider range of participants with the opportunities of institutional, socio-cultural, organizational, and communication support, capable of maintaining the process of functioning of a sole proprietor and ensuring his/her efficiency.

\section{CONCLUSION}

The results obtained contribute to solving the problem of stimulating entrepreneurial activity through enhancing the efficiency of financial and economic regulation of land relations by local governments. The study has considered an opportunity of using industrial land plots to organize entrepreneurial activity by the unemployed based on the principles of covering the value of leasing such plots and land tax at the expense of funds of unemployment benefits provided by the Unemployment Benefit Social Insurance Fund. High efficiency of financial and economic regulation of land relations is achieved through accumulating local budget revenues from lease fees and land tax paid by the previously unemployed persons registered as sole proprietors. The fact of state registration of sole proprietors leads to the legitimization of small business in Ukraine. It is offered to improve the efficiency of financial and economic regulation of land relations in terms of stimulating entrepreneurship through: allocating borrowed resources between economic entities depending on the maximum economic effect; adhering to 
the ratio between amounts of resources and the number of the unemployed under competitive conditions; involving material and financial resources based on the principles of economic feasibility, saving, and rational use.

In regions with low indicators of the efficiency of financial and economic regulation of land relations associated with the use of industrial lands, it is proposed to establish lower marginal amounts of lease fees and land tax rates - at the level of 1-2\% of the normative monetary evaluation. In regions with low indicators of the efficiency of financial and economic regulation of land relations associated with the involvement of the unemployed in entrepreneurial activity, it is proposed to involve additional industrial lands or to "unbundle" already allocated ones together with lease objects located on them.

The development of an ecosystem to support entrepreneurship, along with a determined circle and authority of an entrepreneurial community, will be an appropriate argument for confirming the feasibility of further analysis and initiating scientific search. The entrepreneurship support ecosystem as a type of ecosystems in the economy will allow co-operating the authority of participators to stabilize regional development. To implement a comprehensive reciprocally beneficial initiative, it is advisable to work out the principles of interaction between additional participants and implement innovations by sole proprietors at the level of priority sectors of regional development.

\section{AUTHOR CONTRIBUTIONS}

Conceptualization: Uliana Vatamanyuk-Zelinska.

Formal analysis: Uliana Vatamanyuk-Zelinska, Oleksandr Melnychenko.

Funding acquisition: Uliana Vatamanyuk-Zelinska, Oleksandr Melnychenko.

Investigation: Uliana Vatamanyuk-Zelinska, Oleksandr Melnychenko.

Methodology: Uliana Vatamanyuk-Zelinska, Oleksandr Melnychenko.

Visualization: Uliana Vatamanyuk-Zelinska, Oleksandr Melnychenko.

Writing - original draft: Uliana Vatamanyuk-Zelinska, Oleksandr Melnychenko.

Writing - review \& editing: Uliana Vatamanyuk-Zelinska, Oleksandr Melnychenko.

\section{REFERENCES}

1. Asatryan, Z., Baskaran, T., \& Heinemann, F. (2017). The Effect of Direct Democracy on the Level and Structure of Local Taxes. Regional Science and Urban Economics, 65, 38-55. https:// doi.org/10.1016/j.regsciurbeco.2017.04.006

2. Atamanchuk, H. V. (2006). Upravlenie: sushchnost, tsennost, effektivnost [Management: essence, value, efficiency]. Moscow: Akademicheskii Proekt. (In Russian).

3. Buhlak, Yu. (2018). Problemy rozmezhuvannia povnovazhen mizh orhanamy vykonavchoi vlady i orhanamy mistsevoho samovriaduvannia v Ukraini [Problems of delimitation of powers between executive bodies and local government agencies in Ukraine]. Pidpryiemnytstvo, Hospodarstvo i Pravo - Entrepreneurship, Economy and Law, 11, 70-75. (In Ukrainian). Retrieved from http://pgp-journal.kiev.ual archive/2018/11/15.pdf

4. Dropa, Ya. (2017). Finansovi resursy rozvytku natsionalnoi ekonomiky Ukrainy [Financial resources for the development of the national economy of Ukraine]. Lviv: Ivana Franko LNU. (In Ukrainian).

5. Gobey, M., \& Matikonis, K. (2019). Small Business Property Tax Reductions and Job Growth. Small Business Economics. https://doi. org/10.1007/s11187-019-00219-9

6. Grégoire, D. A., \& Cherchem, N. (2020). A Structured Literature Review and Suggestions for Future
Effectuation Research. Small Business Economics, 54, 621-639. https://doi.org/10.1007/s11187019-00158-5

7. Kaziuk, Ya. M. (2016). Detsentralizatsiia. Mistsevi biudzhety 159 obiednanykh terytorialnykh hromad [Decentralization. Local budgets of 159 united territorial communities]. Kyiv: Ministry of Regional Development, Building and Housing and Communal Services of Ukraine. (In Ukrainian). Retrieved from https://despro.org. ua/despro/Local\%20Budgets $\% 20$ of\%20ACs.pdf

8. Koroteyev, M., Korman, I., Manziy, O., Semenda, O., \& Semenda, O. (2017). Prospects for the Market Turnover of Agricultural Land in Ukraine. Problems and Perspectives 
in Management, 15(2-2), 344-

354. http://dx.doi.org/10.21511/ ppm.15(2-2).2017.04

9. Kotliarevskyi, O. (2014). Formuvannia ukrainskoi modeli aktyvizatsii pidpryiemnytskoi diialnosti [Formulating the Ukrainian model of business intensification]. Skhid - East, 4, 20-24. (In Ukrainian). Retrieved from http://nbuv. gov.ua/UJRN/Skhid_2014_4_4

10. Krysak, A. I. (2015). Stsenarii otsiniuvannia efektyvnosti rehuliuvannia zemelnykh vidnosyn $\mathrm{v}$ umovakh staloho rozvytku [Scenario for evaluating the effectiveness of regulation of land relations in the context of sustainable development]. Aktualni Problemy Ekonomiky - Actual Problems of Economics, 6, 248-257. (In Ukrainian). Retrieved from http://nbuv. gov.ua/UJRN/ape_2015_6_32

11. Krysovatyy, A., Kyrylenko, O., Kneysler, O. et al. (2017). Modern tendencies of fiscal policy in European economic space (388 p.). Ternopil: TNEU. Retrieved from http://dspace.tneu.edu.ua/ handle/316497/30021

12. Kyiv School of Economics. (2018) Serednie znachennia normatyvnoi hroshovoi otsinky zemel nesilskohospodarskoho pryznachennia [The average value of the normative monetary valuation of non-agricultural land]. (In Ukrainian). Retrieved from http://www.kse.org.ua/download.php? downloadid=1109

13. Melnychenko, O. (2015). Regarding the Problem of Work Esteem. European Cooperation, 7(7), 84-91. Retrieved from http:// we.clmconsulting.pl/index.php/we/ article/view/94

14. Morshchenok, T. S. (2016). Ohliad pidkhodiv do vyznachennia ekonomichnoi sutnosti poniattia "efektyvnist" [Review of approaches to defining the economic essence of the concept of "efficiency"]. Ekonomichnyy visnyk Zaporizkoi derzhavnoi inzhenernoi akademii - Economic Herald of Zaporizhzhia State Engineering Academy, 1, 7-13. (In Ukrainian). Retrieved from http://nbuv.gov.ua/UJRN/evzdia_2016_1_3

15. Pikhotskyi, V., \& Rysin, V. (2019). State Control and Public Audit in the Management of Public Finances. European Cooperation, 1(41), 38-51. https://doi.org/10.32070/ ec.v1i41.20

16. Polehenka, M. A. (2016). The theoretical essence of economic categories "efficiency". Agrosvit, 10, 69-74. (In Ukrainian). Retrieved from http://www.agrosvit.info/ pdf/10_2016/12.pdf

17. Potomkina, Yu. S. (2013). Zastosuvannia tekhnolohii "kluichvykh pokaznykiv efektyvnosti" v publichnomu upravlinni [Using the "key performance indicators" technology in public administration]. Bulletin of the National Academy for Public Administration under the President of Ukraine, 3, 64-69. (In Ukrainian). Retrieved from http://nbuv.gov.ua/ UJRN/Vnadu_2013_3_12

18. Prykhodchenko, L. (2007). Shchodo sutnosti poniattia "efektyvnist" v systemi demokratychnoho vriaduvannia [On the essence of the concept of "efficiency" in the system of democratic governance.]. Actual Problems of Public Administration, 3(31), 57-65. (In Ukrainian).

19. Roundy, Ph. T., \& Fayard, D. (2019). Dynamic Capabilities and Entrepreneurial Ecosystems: The Micro-Foundations of Regional Entrepreneurship. The Journal of Entrepreneurship, 28(1), 94-120. https://doi. org/10.1177/0971355718810296

20. Shchehliuk, S. D. (2017). Pidkhody do vyznachennia efektyvnosti realizatsii pidpryiemnytskoho potentsialu rehionu $\mathrm{v}$ umovakh zmin prostorovoi orhanizatsii ekonomiky [Approaches to determining the effectiveness of the entrepreneurial potential of the region in terms of changes in the spatial organization of the economy]. Regional Economy, 4, 22-27. (In Ukrainian). http:// re.gov.ua/doi/re2017.04.022_u.php

21. State Statistics Service of Ukraine. (2016). Richnyi zvit pro vykonannia Derzhavnoho biudzhetu Ukrainy za 2015 rik [Annual report on the execution of the State Budget of Ukraine for 2015]. (In Ukrainian). Retrieved from https://www.treasury.gov.ua/ua/file-storage/richniyzvit-pro-vikonannya-derzhavnogobyudzhetu-ukraini-za-2015-rik
22. State Statistics Service of Ukraine. (2017). Richnyi zvit pro vykonannia Derzhavnoho biudzhetu Ukrainy za 2016 rik [Annual report on the execution of the State Budget of Ukraine for 2016]. (In Ukrainian). Retrieved from https://www.treasury.gov.ua/ua/file-storage/richniyzvit-pro-vikonannya-derzhavnogobyudzhetu-ukraini-za-2016-rik

23. State Statistics Service of Ukraine. (2018a). Richnyi zvit pro vykonannia Derzhavnoho biudzhetu Ukrainy za 2017 rik [Annual report on the execution of the State Budget of Ukraine for 2017]. (In Ukrainian). Retrieved from https://www. treasury.gov.ua/ua/file-storage/ richniy-zvit-pro-vikonannyaderzhavnogo-byudzhetu-ukrainiza-2017-rik

24. State Statistics Service of Ukraine. (2018b). Bezrobitne naselennia (za metodolohiieiu MOP) za tryvalistiu poshuku roboty u 2010-2018 rr. [Unemployed population (according to the MOP methodology) according to the duration of job search in 2010-2018]. (In Ukrainian). Retrieved from https://ukrstat.org/ uk/operativ/operativ2006/rp/ean/ ean_u/arh_brntp_rik_u.htm

25. State Statistics Service of Ukraine. (2019). Richnyi zvit pro vykonannia Derzhavnoho biudzhetu Ukrainy za 2018 rik [Annual report on the execution of the State Budget of Ukraine for 2018]. (In Ukrainian). Retrieved from https://www.treasury.gov.ua/ua/file-storage/richnijzvit-pro-vikonannya-derzhavnogobyudzhetu-ukrayini-za-2018-rik

26. State Statistics Service of Ukraine. (2020). Richnyi zvit pro vykonannia Derzhavnoho biudzhetu Ukrainy za 2019 rik [Annual report on the execution of the State Budget of Ukraine for 2019]. (In Ukrainian). Retrieved from https://www.treasury.gov.ua/ua/file-storage/richnijzvit-pro-vikonannya-derzhavnogobyudzhetu-ukrayini-za-2019-rik

27. The Cabinet of Ministers of Ukraine. (2009, June 17). Pro skhvalennia Kontseptsii Derzhavnoi tsiliovoi prohramy rozvytku zemelnykh vidnosyn $v$ Ukraini na period do 2020 roku (Rozporiadzhennia No. 743-p) [On approval of the State Concept target land development 
program relations in Ukraine for the period up to 2020 (Solution No. 743r)]. (In Ukrainian). Retrieved from https://zakon.rada.gov.ua/laws/ show/743-2009-\%D1\%80

28. The Cabinet of Ministers of Ukraine. (2014, April 1). Pro skhvalennia Kontseptsii reformuvannia mistsevoho samovriaduvannia ta terytorialnoi orhanizatsii vlady $v$ Ukraini (Rozporiadzhennia No. 333-p) [On approval of the Concept of reforming local self-government and territorial organization of power in Ukraine (Solution No. 333$r)]$. (In Ukrainian). Retrieved from https://zakon.rada.gov.ua/laws/ show/333-2014-\%D1\%80

29. The Cabinet of Ministers of Ukraine. (2016, July 6). Pro zatverdzhennia biudzhetu Fondu zahalnooboviazkovoho derzhavnoho sotsialnoho strakhuvannia na vypadok bezrobittia na 2016 rik (Postanova No. 414) [About approval of the budget of Fund of the obligatory state social insurance in case of unemployment for 2016 (Decree No. 414)]. (In Ukrainian). Retrieved from https://zakon. rada.gov.ua/laws/show/414-2016$\% \mathrm{D} 0 \% \mathrm{BF}$

30. The Cabinet of Ministers of Ukraine. (2017, March 1). Pro zatverdzhennia biudzhetu Fondu zahalnooboviazkovoho derzhavnoho sotsialnoho strakhuvannia na vypadok bezrobittia na 2017 rik (Postanova No. 102) [About approval of the budget of Fund of the obligatory state social insurance in case of unemployment for 2017 (Decree No. 102)]. (In Ukrainian). Retrieved from https://zakon. rada.gov.ua/laws/show/102-2017$\% \mathrm{D} 0 \% \mathrm{BF}$

31. The Cabinet of Ministers of Ukraine. (2018, February 7). Pro zatverdzhennia biudzhetu Fondu zahalnooboviazkovoho derzhavnoho sotsialnoho strakhuvannia na vypadok bezrobittia na 2018 rik (Postanova No. 54) [On approval of the budget of the Fund of the obligatory state social insurance in case of unemployment for 2018 (Decree No. 54)]. (In Ukrainian). Retrieved from https://zakon.rada.gov.ua/ laws/show/54-2018-\%D0\%BF

32. The Cabinet of Ministers of Ukraine. (2019a, January 16). Pro zatverdzhennia biudzhetu Fondu zahalnooboviazkovoho derzhavnoho sotsialnoho strakhuvannia na vypadok bezrobittia na 2019 rik (Postanova No. 17) [On approval of the budget of the Fund of the obligatory state social insurance in case of unemployment for 2019 (Decree No. 17)]. (In Ukrainian). Retrieved from https://zakon.rada.gov.ua/ laws/show/17-2019-\%D0\%BF

33. The Cabinet of Ministers of Ukraine. (2019b, July 24). Pro vnesennia zmin do dodatka do postanovy Kabinetu Ministriv Ukrainy vid 26 lystopada 2014 r. No. 675 (Postanova No. 655) [About modification of the appendix to the resolution of the Cabinet of Ministers of Ukraine as of November 26, 2014 No. 675 (Decree No. 655)]. (In Ukrainian). Retrieved from http:// search.ligazakon.ua/1_doc2.nsf/ link1/KP190655.html

34. The Ministry of Social Policy of Ukraine. (2015, June 15). Pro zatverdzhennia Poriadku nadannia dopomohy po bezrobittiu, u tomu chysli odnorazovoi yii vyplaty dlia orhanizatsii bezrobitnym pidpryiemnytskoi diialnosti (Nakaz No. 613) [On approval of the Procedure for unemployment assistance, including the one-time payment to organize business activity to unemployed (Order No. 613)]. (In Ukrainian). Retrieved from https:// zakon.rada.gov.ua/laws/show/ z0821-15

35. The Verkhovna Rada of Ukraine. (1997). Pro mistseve samovriaduvannia v Ukraini. Zakon Ukrainy vid 21 travnia 1997 roku No. 280/97-VR [About local selfgovernment in Ukraine. Law of Ukraine dated May 21, 1997 No. 280/97-VR]. Vidomosti Verkhovnoi Rady (VVR), 24, st. 170. (In Ukrainian). Retrieved from https://zakon. rada.gov.ua/laws/show/280/97\%D0\%B2\%D1\%80\# Text

36. The Verkhovna Rada of Ukraine. (2001). Zemelnyi kodeks Ukrainy [Land Code of Ukraine]. (In Ukrainian). Retrieved from https://zakon. rada.gov.ua/laws/show/2768-14

37. The Verkhovna Rada of Ukraine. (2010). Podatkovyi kodeks Ukrainy [Tax Code of Ukraine]. (In Ukrainian). Retrieved from https://zakon. rada.gov.ua/laws/show/2755-17
38. The Verkhovna Rada of Ukraine. (2017). Poiasniuvalna zapyska do proektu Zakonu Ukrainy "Pro vnesennia zmin do deiakykh zakonodavchykh aktiv Ukrainy (shchodo vrehuliuvannia poriadku nadannia v orendu zemel, yaki perebuvaiut u postiinomu korystuvanni)" [Explanatory note to the draft law of Ukraine "On Amendments to Certain Legislative Acts of Ukraine (regarding regulation of the procedure for leasing land in permanent use)"] No. 6262. (In Ukrainian). Retrieved from http:// search.ligazakon.ua/1_doc2.nsf/ link1/GH4TY00A.html

39. Vatamanyuk-Zelinska, U., \& Sytnyk, N. (2019). Effectiveness of Financial and Economic Regulation of Land Relations in Ukraine in the Context of the Decentralization Reform. Problems and Perspectives in Management, 17(2), 550-562. http://dx.doi.org/10.21511/ ppm.17(2).2019.43

40. Watamanyuk-Zelinska, U. Z., \& Malets, P. I. (2018). Effective Management of Municipal of Property in the Context of Decentralized Processes in State Development. Effective Economy, 9. Retrieved from http://www.economy.nayka.com. ua/?op $=1 \& z=6520$

41. Zhytomyr.info. (2018). Za rik bezrobitni Zhytomyrskoi oblasti otrymaly 654 tys. hrn na vidkryttia vlasnoi spravy, tsoho roku sumu zbilshyly [During the year, the unemployed of Zhytomyr region received 654 thousand UAH to start their own business, this year the amount increased]. (In Ukrainian). Retrieved from https://www.zhitomir.info/news_173722.html 